Editorial

\title{
Occupational reconstructions: resources for social transformation in challenging times
}

\author{
Gelya Frank ${ }^{\mathrm{a}}$ (D), Vagner dos Santos ${ }^{\mathrm{b}}$ (D) \\ ${ }^{a}$ Mrs. T. H. Chan Division of Occupational Science \& Occupational Therapy, Department of Anthropology, \\ University of Southern California, Los Angeles, CA, USA. \\ ${ }^{\mathrm{b} S}$ chool of Community of Health, Charles Sturt University, Port Macquarie, NSW, Australia.
}

How to cite: Frank, G., \& Santos, V. (2020). Occupational reconstructions: resources for social transformation in challenging times. Cadernos Brasileiros de Terapia Ocupacional, 28(3), 741-745. https://doi.org/10.4322/2526-8910.ctoED2802

\section{Occupational Reconstructions: Resources for Social Transformation in Challenging Times}

We are living in challenging times. Whether in the Global South or Global North, an alarming sweep of nationalism, populism, authoritarianism and racism threatens the health, wellbeing, rights and freedom of millions. The report Democracy in Retreat: Freedom in the World 2019 notes a steady decline over the past 13 years in measures of freedom and democracy throughout the world (Freedom House, 2019). The aggregate scores for Brazil (75/100) and the United States (86/100) lag behind countries mostly in northern and western Europe but also regionally-e.g. Uruguay (98/100) and Canada (99/100).

These trends pose disproportionate risks to the most vulnerable. They include increasing economic inequality, reduced public services, dismantling of legal protections, fewer educational opportunities, inadequate and insufficient housing, unemployment, underemployment and poor-quality jobs, diminished access to health care, and deteriorating environments. Such conditions erode people's resources and capacities to improve their own lives. These conditions of inequality and disadvantage are being revealed, even more, by the current global crisis due to the COVID-19 pandemic.

This editorial calls attention to a theory of hopeful collective action and radical social transformation, a theory of 'occupational reconstruction' (Frank, 2020). What is radical about it? It is radical because it comes from the roots of daily experience. And it calls on our basic human capacities for self-organization and cooperative action to solve problems creatively.

\subsection{It's a problematic situation: hope and engagement for a better today!}

Who is most at risk? Women, children, the unemployed, the structurally poor, people who are homeless, migrants, refugees, indigenous peoples, sexual and religious minorities, and people of African descent and cultures, as well as those with physical, developmental, psychological and cognitive disabilities, and chronic illnesses. Our patients and clients, students and their families, co-workers and neighbors, and 
perhaps we ourselves will find access to human rights, civil rights and other social goods becoming more fragile.

As an internationally recognized profession, occupational therapy has certain resources in its knowledge base and practice orientation to defend the rights and strengthen the capacities of those at risk. Among the 72 member countries in the World Federation of Occupational Therapy, Brazil has been a leader in expanding the profession's scope of practice to address social inclusion and social transformation (Lopes \& Malfitano, 2016; Santos, 2017). At the same time, the profession's academic legitimacy and research capacity has grown exponentially since the PhD degree-granting discipline of occupational science was introduced in the United States (Yerxa et al., 1990; Clark et al., 1991).

The profession of occupational therapy and discipline of occupational science share a foundational commitment. They both aim to ameliorate disabling conditions by supporting the capacities of people to handle life's challenges. Together, the profession and discipline share the purpose to help people participate more fully and successfully in their social worlds. They do this not by imposing norms, and not all at once, but in concrete steps marked by active, engaged experiences. In the United States, where occupational therapy was incorporated as a profession in 1917, this orientation, called meliorism, springs from the pragmatist philosophy and social reform activism of John Dewey and Jane Addams (Baranek et al., Under review; also see Frank \& Zemke, 2009; Morrison, 2016; Cunha \& Garcia, 2011).

Meliorism is the idea that "[...] we are capable of creating better worlds and selves" (Koopman, 2006, p. 107). It is part of a coherent philosophy about life as an ongoing process of problem-solving toward desired 'ends-in-view.' Its method involves engaged and awakened experiences-i.e. the search for truth--not prescriptions and pre-determined protocols (Schneiderhan, 2011). It is a realistic but hopeful philosophy that starts with 'where we are now' and, through the effort of problem-solving, can increase knowledge and capacities for self-empowerment and transformative action.

Descriptions, models and frameworks of social transformative practice in the Global South and Global North now overflow volumes of the edited books about 'occupational therapies without borders' (Kronenberg et al., 2005, 2011; Pollard et al., 2009; Sakellariou \& Pollard, 2017). Yet this is only a beginning (Guajardo et al., 2015; Magalhães, 2012; Van Bruggen et al., 2020). Occupational Reconstruction Theory, which we describe below, is one of the emerging tools that holds promise for occupational therapy's practice at the social level.

\subsection{Occupational reconstruction as a practice framework}

Occupational reconstructions occur when a group of people decides together 'to do something about something'. The theory of occupational reconstruction explains the transformative elements at play. Occupational reconstructions have the following key elements: They take place as embodied events in space and time. They arise through voluntary and intrinsic motivation (i.e. a desire) for change. Collective action depends on a degree of shared purpose and meaning, which arises by aligning the histories and identities of the participants through narratives. Participation and emotional 
commitment are reinforced by the excitement of creative opportunities related to experimenting reality-and also by the risks, since desired outcomes cannot be guaranteed.

Although Occupational Reconstruction Theory works with concepts and examples found in social movement studies, its background in pragmatism and the knowledge base of the profession of occupational therapy contributes a unique, in-depth understanding of actual 'doing'. We know that 'doing' is more complex than meets the eye. It is a bio-psycho-social process. Occupation ('doing something') mediates relationships between persons and their environment, and between the self and society. Because of this background, Occupational Reconstruction Theory offers a means: (i) to understand collective actions to ameliorate social problems; (ii) to promote critical education and capacities for socially transformative action; and (iii) to guide professional practice.

Models for occupational reconstruction can be found in the American civil rights and South African anti-apartheid movements (Frank \& Muriithi, 2015) and in NGO efforts to rebuild Guatemalan society after a devastating civil war (Frank, 2013). Instructional materials used at the University of Southern California include a one-page training guide with examples of occupational reconstructions from major documentary films accessible on the internet (Frank, 2017, 2020). Santos et al. (In press) describe a course at the University of Brasilia, Ceilandia (FCE), guiding students: (i) to interview their parents and grandparents about their collective efforts to fight poverty and marginalization; and (ii) to create public documents based on histories of collective action in a local narrative form (literatura de cordel) (Mizue, 2019; Reconstrução Ocupacional Candanga, 2019).

\section{Conclusion}

There is growing sense that the future of life on earth is not only bleak but beyond repair. The decline in political opportunities for the majority of people in most countries may foster social disengagement, passive suffering and inaction. Yet occupational therapy's philosophy and knowledge base supports taking action to improve problematic situations through hope and engagement. We are seeing this in the public's rapid and spontaneous response to the pandemic in acts of solidarity, shared resources and political response on the Internet and through in-person networks. More widespread work on occupational reconstructions is needed to build collaborative models for practice with measurable outcomes. Occupational Reconstruction Theory, we suggest, provides a workable framework for moving occupational therapy knowledge into practice to support people's capacities to make better worlds.

\section{References}

Baranek, G. T., Frank, G., \& Aldrich, R. M. (Under review). Meliorism and knowledge mobilization: past, present, and future possibilities for occupational science. Journal of Occupational Science.

Clark, F., Parham, D., Carlson, M. E., Frank, G., Jackson, J., Pierce, D., Wolfe, R. J., \& Zemke, R. (1991). Occupational science: academic innovation in the service of occupational therapy's future. The American Journal of Occupational Therapy, 45(4), 300-310. PMid:2035601. http://dx.doi.org/10.5014/ajot.45.4.300. 
Cunha, M., \& Garcia, D. (2011). Pragmatism in Brazil: John Dewey and education. In G. Pappas (Ed.), Pragmatism in the Americas (pp. 40-52). New York: Fordham University Press. Retrieved in 2020, January 30, from www.jstor.org/stable/j.ctt14brzwr.6

Frank, G. (2013). Twenty-first century pragmatism and social justice: problematic situations and occupational reconstructions in post-civil war Guatemala. In M. Cutchin \& V. Dickie (Eds.), Transactional perspectives on occupation (pp. 229-243). Dordrecht: Springer. http://dx.doi.org/10.1007/978-94-007-4429-5_18.

Frank, G. (2017). Collective occupations and social transformations: a mad hot curriculum. In N. Pollard $\&$ D. Sakellariou. Occupational therapies without borders: integrating justice with practice (pp. 596604). Edinburgh: Elsevier Press.

Frank, G. (2020). Social transformation theory and practice: resources for radicals in participatory art, occupational therapy and social movements. In H. Van Bruggen, S. Kantartzis \& N. Pollard (Eds.), And a seed was planted (pp. 107-128). London: Whiting \& Birch.

Frank, G., \& Muriithi, B. A. K. (2015). Theorizing social transformation in occupational science: the American civil rights movement and South African struggle against apartheid as 'occupational reconstructions'. Journal of South African Occupational Therapy, 45(1), 11-19. http://dx.doi.org/10.17159/2310-3833/2015/v45no1a3.

Frank, G., \& Zemke, R. (2009). Occupational therapy foundations for political engagement and social transformation. In N. Pollard, D. Sakellariou \& F. Kronenberg (Eds.), A political practice of occupational therapy (pp. 111-135). Edinburgh: Churchill Livingstone.

Freedom House. (2019). Democracy in retreat: freedom in the world 2019. Retrieved in 2020, January 30 , from https://freedomhouse.org/report/freedom-world/freedom-world-2019/democracy-in-retreat

Guajardo, A., Kronenberg, F., \& Ramugondo, E. L. (2015). Southern occupational therapies: emerging identities, epistemologies and practices. South African Journal of Occupational Therapy, 45(1), 3-10. http://dx.doi.org/10.17159/2310-3833/2015/v45no1a2.

Koopman, C. (2006). Pragmatism as a philosophy of hope: Emerson, James, Dewey, Rorty. The Journal of Speculative Philosophy, 20(2), 106-116. http://dx.doi.org/10.1353/jsp.2006.0020.

Kronenberg, F., Pollard, N., \& Sakellariou, D. (2011). Occupational therapies without borders. Edinburgh: Elsevier.

Kronenberg, F., Simó Algado, S., \& Pollard, N. (2005). Occupational therapy without borders: learning from the Spirit of Survivors. Edinburgh: Elsevier/Churchill Livingstone.

Lopes, R. E., \& Malfitano, A. P. S. (2016). Terapia ocupacional social: desenhos teóricos e contornos práticos. São Carlos: EdUFSCar.

Magalhães, L. (2012). What would Paulo Freire think of occupational science? In G. Whiteford \& C. Hocking (Eds.), Occupational science society, inclusion, participation (pp. 8-19). Chichester: WileyBlackwell. http://dx.doi.org/10.1002/9781118281581.ch2.

Mizue, A. (2019). Reconstrução ocupacional: experiências no Distrito Federal (Bachelor's thesis). Universidade de Brasília, Brasília.

Morrison, R. (2016). Pragmatist epistemology and Jane Addams: fundamental concepts for the social paradigm of occupational therapy. Occupational Therapy International, 23(4), 295-304. PMid:27245105. http://dx.doi.org/10.1002/oti.1430.

Pollard, N., Sakellariou, D., \& Kronenberg, F. (Eds.). (2009). A political practice of occupational therapy. Philadelphia: Elsevier.

Reconstrução Ocupacional Candanga. (2019). Retrieved in 2020, January 30, from http://reconstrucaoocupacionalcandanga.blogspot.com/

Sakellariou, D., \& Pollard, N. (2017). Occupational therapies without borders: integrating justice with practice. Edinburgh: Elsevier. 
Santos, V. (2017). Occupational therapy across South America: an overview of its backgrounds, current situation and some contemporary issues. In D. Sakellariou \& N. Pollard (Eds.), Occupational therapies without borders: integrating justice with practice (pp. 203-209). Edinburgh: Elsevier Science.

Santos, V., Frank, G. \& Mizue, A. (In press). Candangos: occupational reconstruction as a tool to understand social problems and transformative action in the utopian city of Brasília. Brazilian Journal of Occupational Therapy.

Schneiderhan, E. (2011). Pragmatism and empirical sociology: the case of Jane Addams and Hull-House, 1889-1895. Theory and Society, 40(6), 589-617. http://dx.doi.org/10.1007/s11186-011-9156-2.

Van Bruggen, H., Kantartzis, S., \& Pollard, N. (Eds.). (2020). And a seed was planted. London: Whiting $\&$ Birch.

Yerxa, E. J., Clark, F., Frank, G., Jackson, J., Parham, D., Pierce, D., Stein, C., \& Zemke, R. (1990). An introduction to occupational science, a foundation for occupational therapy in the 21 st century. Occupational Therapy in Health Care, 6(4), 1-17. PMid:23931133.

http://dx.doi.org/10.1080/J003v06n04_04. 